\title{
Keanekaragaman Liana di Hutan Pendidikan Universitas Muhammadiyah Bengkulu, Kabupaten Bengkulu Tengah
}

\author{
The Diversity of Liana in Educational Forest of Muhammadiyah University \\ of Centre Bengkulu
}

\author{
Rusdi Hasan*, Anggi Yuniarti, Kasmiruddin \\ Universitas Muhammadiyah Bengkulu, Jalan Bali 118 \\ KOTA BENGKULU, 38119 \\ Correspondence author: rusdihasan@gmail.com
}

Manuscript received: 29-03-2018. Accepted: 28-04- 2018

\begin{abstract}
ABSTRAK
Penelitian ini bertujuan untuk mengetahui jenis-jenis tumbuhan jenis Liana yang terdapat di Hutan Pendidikan Universitas Muhammadiyah Bengkulu, Kabupaten Bengkulu Tengah pada kawasan hutan lindung Bukit Barisan, Kabupaten Kepahyang Propinsi Bengkulu sehingga dapat memberikan informasi potensinya secara ekonomi maupun kepentingan konservasi. Penelitian ini menggunakan metode survey langsung ke lokasi pada bulat Maret sampai Mei 2107. Pengambilan sampel dilakukan pada petak-petak yang dibuat mengikuti jalur transek pada hutan yang bersuhu udara $27-31^{\circ} \mathrm{C}$ dan kelembaban udara 76-87\%. Hasil penelitian menemukan 20 spesies tumbuhan Liana termasuk dalam 9 famili. Famili Asteraceae terdiri dari 1 spesies yaitu Mikania micrantha, famili Araceae terdiri dari 1 spesies yaitu Pothos scandens, famili Convolvulaceae terdiri dari 4 spesies yaitu Ipomoea triloba, Ipomoea cairica, Merremia peltata, Merremia vitifolia, famili Dioscoreaceae terdiri dari 1 spesies yaitu Dioscorea hispida, famili Fabaceae terdiri dari 2 spesies yaitu Calopogonium mucunoides, Centrosema pubescens, famili Menispermaceae terdiri dari 3 spesies yaitu Cyclea barbata, Pericampylus glaucus, Tinospora crispa, famili Palmae terdiri dari 4 spesies yaitu Calamus caesius, Calamus manan, Daemonorops sabut, Korthalsia rigida, famili Piperaceae terdiri dari 3 spesies yaitu Piper betle, Piper nigrum, Piper ornatum, famili Schizaeaceae terdiri dari 1 spesies yaitu Lygodium flexuosum.
\end{abstract}

Kata kunci : Bukit Barisan, hutang lindung, keanekaragaman, transect

\begin{abstract}
This study aims to determine the types of Liana plants found in Educational Forest of Muhammadiyah University of Centre Bengkulu within Conservation Forest of Bukit Barisan located in Kepahyang Regency of Bengkulu Province. This survey method research was conducted on March-April 2017. Sampling was collected in the plots placed along transect line in the forest which have temperature range from $27-31^{\circ} \mathrm{C}$ and humidity range $76-87 \%$. The result found that of 20 Liana plants species belong to 9 families. Asteraceae family consist of 1 species of Mikania micrantha, family Araceae consist of 1 species of Pothos scandens, family Convolvulaceae consist of 4 species namely Ipomoea triloba, Ipomoea cairica, Merremia peltata, Merremia vitifolia, family Dioscorea consist of 1 species of Dioscorea hispida, family Fabaceae consist of 2 species of Calopogonium mucunoides,
\end{abstract}


Centrosema pubescens, family Menispermaceae consist of 3 species of Cyclea barbata, Pericampylus glaucus, Tinospora crispa, family Palmae cinsist of 4 species namely Calamus caesius, Calamus manan, Daemonorops sabut, Korthalsia rigida, famili Piperaceae consist of 3 species of Piper betle, Piper nigrum, Piper ornatum, family Schizaeaceae consist of 1 species of Lygodium flexuosum.

Keywords: Bukit Barisan, diversity, forest conservation, transect

\section{PENDAHULUAN}

Provinsi Bengkulu berada di sebelah barat pegunungan Bukit Barisan, terletak di antara $2^{\circ} 16^{\prime \prime}-03^{\circ} 31^{\prime}$ LS dan $101^{\circ} 01^{\prime}-103^{\circ} 41^{\prime}$ BT, diapit oleh Propinsi Sumatera Barat di sebelah utara dan Provinsi Lampung di sebelah Selatan. Bengkulu didominasi oleh perbukitan dengan kawasan hutan seluas 920.964 ha atau $46.54 \%$ dari luas daratan Propinsi Bengkulu (1.978.870 ha). Di antara kawasan hutan di Bengkulu sebagian merupakan hutan lindung Bukit Barisan yang termasuk dalam rangkaian hutan tropis yang terbentang dari Utara hingga Selatan Pulau Sumatera. Sebagai bagian dari hutan hujan tropis, kawasan hutan di Bengkulu memiliki keanekaragaman hayati yang sangat kaya merupakan salah satu tipe vegetasi hutan tertua di muka bumi (Indriyanto, 2010). Berdasarkan SK Menteri Lingkungan Hidup dan Kehutanan Nomor 425/Menlhk/Setjen/PLA.O/6/2016 tentang penetapan kawasan hutan dengan tujuan khusus, dari kawasan hutan lindung tersebut seluas kurang lebih 2.000 ha yang terdapat di Kabupaten Bengkulu Tengah ditetapkan sebagai Hutan Pendidikan dan Pelatihan yang pengelolaannya diserahkan kepada Universitas Muhammadiyah Bengkulu.

Keanekaragaman hayati yang tinggi dimiliki hutan pendidikan Universitas Muhammadiyah Bengkulu ini belum digali potensinya baik untuk tujuan pendidikan, konservasi plasma nuftah yang ada di dalamnya maupun secara ekonomi tanpa mengganggu kelestarian dan keseimbangan ekosistem hutan. Hutan tersebut memiliki kerapatan vegetasi yang tinggi dengan berbagai jenis flora dan fauna. Bahkan di kawasan hutan ini merupakan habitat bagi beberapa jenis flora endemis yakni bunga raflesia dan bunga bangkai yang sudah diketahui beberapa titik sebaran habitatnya pada sebagian hutan lindung ini.

Salah satu jenis tumbuhan yang banyak terdapat dalam ekosisten hutan pendidikan ini adalah jenis tumbuhan memanjat atau tumbuhan liana karena liana merupakan jenis tumbuhan yang melimpah di hutan tropis (Addo-Fordjour et. al., 2016; Hilje and SánchezAzofeifa, 2017). Diantara jenis liana yang memiliki potensi ekonomi tinggi dan dapat dimanfaatkan tanpa merusak atau mengganggu ekosistem hutan adalah rotan yang tumbuh liar di dalam hutan. Rotan merupakan liana yang banyak tumbuh di hutan-hutan Indonesia secara ekonomis bernilai tinggi (Arisandi, 2011; Jasni et.al., 2010). Selain rotan ditemukan juga jenis tumbuhan liana yang tumbuh liar dan belum diketahui oleh masyarakat sekitar. Oleh karena ini perlu dilakukan penelitian tentang keanekaragaman tumbuhan liana yang terdapat di hutan pendidikan dan pelatihan Universitas Muhammadiyah Bengkulu sebagai tahap awal dalam menginvetarisasi kekayaan alam di hutan ini.

\section{BAHAN DAN METODE}

Penelitian telah dilaksanakan pada bulan Februari-Appril 2017 di kawasan Hutan Pendidikan dan Pelatihan Universitas Muhammadiyah Bengkulu pada posisi geografis $03^{\circ} 40^{\prime} 20,59^{\prime \prime}$ LS $102^{\circ} 32$ '53,51" BT. Metode yang digunakan adalah survey langsung ke lokasi penelitian. Sampel diambil pada plot-plot cuplikan yang dibuat secara sistematis sepanjang garis transek. Jumlah garis transek yang dibuat sebanyak 5 garis transek yang 
masing-masing memiliki 5 plot. Panjang transek 105 meter dengan jarak antar transek 25 meter. Plot berukuran 5x5 meter dengan jarak antar plot 20 meter dalam satu garis transek. Jumlah plot keseluruhan sebanyak 25 plot.

Setiap jenis tumbuhan liana yang ditemukan di lapangan diambil sampel bagian tubuhnya untuk melengkapi data morfologi liana yang meliputi akar, batang, daun, dan juga bunga, buah, dan biji. Setiap sampel yang diambil, didokumentasi, dan dibawa ke laboratorium biologi Universitas Muhammadiyah Bengkulu untuk diidentifiksi dan dibuat herbarium.

Indeks keanekaragaman species dalam komunitas ditentukan berdasarkan indeks Shannon-Winnerse bagai berikut:

Dimana :

$$
H=-\Sigma\{(n . i / N) \log (n . i / N)
$$

$$
\begin{aligned}
& \mathrm{H}=\text { indeks keanekaragaman Shannon } \\
& \mathrm{n} . \mathrm{i}=\text { nilai penting dari tiap spesies } \\
& \mathrm{N}=\text { total nilai penting }
\end{aligned}
$$

Kriteria nilai indeks keanekaragaman Shannon-Winner $\left(H^{\prime}\right)$ adalah sebagai berikut :
a. $H^{\prime}<1 \quad$ : menunjukkan bahwa keanekaragaman rendah
b. $1<H^{\prime}<3$ : menunjukkan bahwa keanekaragaman sedang
c. $H^{\prime}>3$ : menunjukkan bahwa keanekaragaman tinggi

\section{HASIL PENELITIAN}

\section{Jenis-jenis tumbuhan liana di hutan pendidikan Universitas Muhammadiyah Bengkulu}

Lokasi penelitian pada kawasan hutan pendidikan Universitas Muhammadiyah Bengkulu berada pada ketinggian $720 \mathrm{dpl}$, suhu siang hari berkisar $27-31^{\circ} \mathrm{C}$ dan kelembaban udara berkisar 76-87\%. Hasil penelitian menemukan 20 spesies liana yang termasuk ke dalam 9 famili. Keragaman jenis tumbuhan liana disajikan dalamTabel 1, frekuensi tumbuhan yang ditemukan disajikan dalamTabel 2, dan indeks keragaman jenisnya disajikan dalam Tabel 3

\section{Deskripsi tumbuhan liana di hutan pendidikan UMB}

Mikania micrantha (sembung rambat). Tumbuhan ini memiliki tangkai dan helaian daun, daun tunggal berbentuk jantung, ujung daunnya runcing, pangkal daun tumpul, tepi daun bergerigi dan berwarna hijau. Batang berbentuk bulat, berbulu halus dan berwarna hijau muda. Akar serabut, memiliki kuncup tertutup atau pelindung kuncup. Bunga berukuran kecil dan berwarna putih.

Pothos scandens (klabangan). Tumbuhan ini memiliki tangkai daun yang panjang dan helaian daun, daun berbentuk bangun lanset, dengan ujung daun runcing, pangkal daun tumpul, susunan tulang daun menyirip. Batang berbentuk bulat, lunak, serta berbuku-buku, disetiap buku pada batangnya ditumbuhi akar lekat dan memiliki akar tunggang.

Ipomoea triloba (ubi jalar hutan). Tumbuhan ini memiliki tangkai daun dan helaian daun, ujung, daun tumpul, susunan tulang daun menyirip, daun berbentuk hati, memiliki tiga lobus dan berbulu halus. Bentuk batang bulat, tipis dan berbulu halus, memiliki akar serabut. Memiliki kuncup yang tertutup atau pelindung kuncup, kuncupnya tumbuh dibagian ketiak daun. Bunga berbentuk lonceng, warnanya cukup bervariasi dalam warna pink, merah atau lavender, dengan atau tanpa tanda putih. 
Ipomoea cairica (ubi kates). Ipomoea cairica memiliki tangkai serta helaian daun, daun berbentuk bangun lanset, ujung daun meruncing, pangkal daun tumpul, susunan tulang daun menyirip, permukaan daun licin suram, daun memiliki lima lobus. Batang berbentuk bulat kecil, memiliki akar serabut. Kuncup tidak memiliki pelindung, kuncup tumbuh dibagian ketiak daun. Bunga berbentuk terompet, berwarna merah sampai keunguan.

Merremia peltata (daun bulu). Tumbuhan ini memiliki tangkai dan helaian daun, ujung daun tumpul, pangkal daun membulat, susunan tulang daun sejajar, daun tumbuh berselang-seling, tepi atau bentuk daun berlekuk, permukaan daun kasap. Bentuk batang bulat dan bercabang-cabang, memiliki kuncup tertutup atau pelindung kuncup. Kuncup tumbuh dibagian ketiak daun. Bunga berbentuk terompet dan berwarna putih hingga kuning cerah.

Merremia vitifolia (akar bulu). Tumbuhan ini memiliki tangkai dan helaian daun, ujung daun meruncing, pangkal daun membulat, susunan tulang daun menyirip, tepi daun bergerigi, permukaan daun kasap, daun tua berwarna hijau dan yang muda berwarna cokelat kemerahan. Daunnya memiliki lima lobus serta berbulu halus, berbatang bulat kecil dan berbulu halus. Berakar serabut, kuncup tidak memiliki pelindung, bunga berbentuk terompet dan berwarna kuning.

Dioscorea hispida (gadung). Tumbuhan ini memiliki tangkai dan helaian daun, ujung daun runcing, pangkal daun membulat, susunan tulang daun melengkung. Batang berbentuk bulat dan berduri, memiliki warna hijau dan keabu-abuan. Menghasilkan umbi yang terbentuk di dalam tanah, berjumlah banyak dan bentuknya tak beraturan.

Calopogonium mucunoides (kacang asu). Tumbuhan ini memiliki tangkai dan helaian daun, bentuk daun membulat, ujung daun tumpul, permukaan daun kasap dan berbulu halus. Bentuk batang bulat halus dan memiliki bulu halus. Berakar serabut, kuncup tertutup atau memiliki pelindung kuncup. Memiliki bunga yang berwarna biru atau keunguan.

Centrosema pubescens (kembang telang). Tumbuhan ini memiliki tangkai dan helaian daun, berdaun tiga, bentuk daun majemuk dan bundar telur, ujung daun tumpul, pangkal daun membulat, permukaan daun licin suram. Berbatang bulat dan sedikit berbulu, memiliki buah berupa polong, biji berbentuk lonjong dan berwarna hitam kecokelatan. Memiliki kuncup tertutup atau pelindung kuncup, bunga berwarna keunguan dan memiliki akar serabut.

Cyclea barbata (cincau). Tumbuhan ini memiliki tangkai dan helaian daun, daun berbentuk jantung, ujung daun runcing, pangkal daun membulat, susunan tulang daun melengkung, tangkai daun panjang dan muncul dari lembaran daun bagian belakang, permukaan daun kasap. Berbatang bulat dan berwarna hijau, bunga berwarna kuning kehijauan, buah berukuran kecil dan berwarna merah bila sudah masak.

Pericampylus glaucus (akar telur). Tumbuhan ini memiliki tangkai dan helaian daun, berdaun tunggal, berbentuk jantung dengan ujung daun tumpul, pangkal daun membulat, susunan tulang daun melengkung, permukaan daun licin suram. Batang berbentuk bulat dan sering kali dijadikan pengikat oleh masyarakat karena batangnya kuat dan tahan lama, memiliki akar serabut.

Tinospora crispa (bratawali). Tumbuhan ini memiliki tangkai dan helaian daun, daunnya berbentuk jantung agak membulat, ujung daun runcing, pangkal daun tumoul susunan tulang daun menyirip, permukaan daun licin mengkilap. Berbatang bulat dan berduri semu, lunak berupa bintil-bintil, memiliki bunga yang berukuran kecil dan berwarna hijau. 
Calamus caesius (rotan sega). Tumbuhan ini memiliki tangkai dan helaian daun, bentuk daun meruncing dengan pangkal daun juga runcing, susunan tulang daun sejajar, permukaan daun kasap, daun memiliki pelepah yang berwarna hijau suram. Batang berbentuk bulat, berduri dan tanpa pelepah, duri berbentuk segitiga dan antara duri-duri tersebut terdapat duri yang berwarna abu-abu.

Calamus manan (rotan manau). Tumbuhan ini memiliki tangkai dan helaian daun, tangkai daun pendek, ujung daun dan pangkal daunnya meruncing, susunan tulang daun sejajar, permukaan daun kasap, daun memiliki pelepah yang berwarna hijau keabu-abuan kusam, ditumbuhi duri segitiga yang pinggirnya berbulu hitam, duri ini tertata dalam kelompok-kelompok menyamping atau tersebar acak. Memiliki batang bulat dan diameter batang tanpa pelepah.

Daemonorops sabut (rotan jungan). Tumbuhan ini daun panjang tanpa pelepah, ujung daun meruncing, susunan tulang daun sejajar, permukaan daun kasap berwarna hijau tua, ditumbuhi duri rapat tersebar, bentuk daun segitiga pipih berwarna hitam, memiliki anak daun yang berbentuk jajaran genjang, anak daun berjumlah 7 pasang. Berbatang bulat, tumbuh ramping dan berumpun, berduri segitiga pipih berwarna hitam.

Korthalsia rigida (rotan marau). Tumbuhan ini memiliki tangkai dan helaian daun, tumbuh berumpun, ujung dan pangkal daun runcing, susunan tulang daun sejajar, permukaan daun kasap. Daun berwarna hijau pudar, ditumbuhi duri berwarna cokelat keabu-abuan, durinya berbentuk segitiga dan tersebar dipermukaan pelepah daun, pelepah daun berwarna cokelat keabu-abuan. Batang berbentuk bulat dan batangnya tanpa pelepah.

Piper betle (sirih). Tumbuhan ini memiliki tangkai dan helaian daun, berdaun tunggal berbentuk jantung, ujung daun runcing, pangkal daun tumpul, susunan tulang daun melengkung, permukaan daun licin mengkilap dan kasar bila diraba. Batangnya bulat berwarna hijau kecokelatan, bunganya majemuk berbentuk bulir dan terdapat daun pelindung. Akarnya bulat dan berwarna cokelat kekuningan.

Piper nigrum (lada). Tumbuhan ini memiliki tangkai dan helaian daun, daunnya tunggal berbentuk bulat telur agak membulat, susunan tulang daun melengkung, permukaan daun licin suram, letak daun berselang-seling atau tersebar, memiliki tangkai daun yang cukup panjang, permukaan daun bergelombang. Batangnyan berbentuk bulat, berkayu, berwarna cokelat kemerahan, bercabang banyak dan batangnya berbuku-buku.

Piper ornatum (sirih hutan). Tumbuhan ini memiliki tangkai dan helaian daun, daun tunggal berbentuk jantung dengan ujung daun meruncing, pangkal daun membulat, susunan tulang daun melengkung, permukaan daun licin mengkilap, daun berwarna merah keunguan, pada permukaan daun atas berwarna hijau, pink dan perak, permukaan daunnya bergelombang. Tumbuhan ini tidak memiliki bunga, bila tumbuh pada daerah panas atau terkena cahaya matahari langsung, batangnya mengering.

Lygodium flexuosum (paku hata kembang). Tumbuhan ini memiliki tangkai dan helaian daun, tangkai daun majemuk dan memanjang, daunnya menjari 3-7 lobus, bagian pangkal daun berbentuk seperti jantung, dengan ujung daun runcing, permukaan daun licin mengkilap, daun muda tumbuhan ini mengalami sekali atau dua kali percabangan dikotom. Batangnya berwarna hijau dan berbentuk bulat kecil, tumbuh merambat pada semak belukar atau cabang pohon yang tinggi. 


\section{PEMBAHASAN}

Berdasarkan hasil penelitian yang telah dilakukan di hutan pendidikan dan pelatihan Universitas Muhammadiyah Bengkulu ditemukan spesies tumbuhan Liana sebanyak 20 spesies yang termasuk kedalam 9 famili yaitu : famili Asteraceae 1 spesies yaitu (Mikania micrantha), famili Araceae 1 spesies yaitu (Pothos scanden), famili Convolvulaceae 4 spesies yaitu (Ipomoea triloba, Ipomoea cairica, Merremia peltata, Merremia vitifolia), famili Dioscoreaceae 1 spesies yaitu (Dioscorea hispida), famili Fabaceae 2 spesies yaitu (Calopogonium mucunoides, Centrosema pubescens), famili Menispermaceae 3 spesies yaitu (Cyclea barbata, Pericampylus glaucus, Tinospora crispa), famili Palmae 4 spesies yaitu (Calamus caesius, Calamus manan, Daemonorops sabut, Korthalsia rigida), famili Piperaceae 3 famili yaitu (Piper betle, Piper nigrum, Piper ornatum), famili Schizaeaceae 1 spesies yaitu (Lygodium flexuosum).

Tabel 1. Keanekaragaman Tumbuhan Liana di Hutan Pendidikan dan Pelatihan Universitas Muhammadiyah Bengkulu

\begin{tabular}{lllc}
\hline No & Famili & Nama Spesies & Nama Indonesia \\
\hline 1. & Asteraceae & Mikania micrantha & Sembung rambat \\
2. & Araceae & Pothos scandens & Klabangan tangkai daun panjang \\
& & Ipomoea triloba & \\
3. & Convolvulaceae & Ipomoea cairica & Ubi jalar hutan \\
& & Merremia peltata & Ubi kates \\
& & Merremia vitifolia & Daun bulu \\
& & Dioscorea hispida & Akar bulu \\
4. & Dioscoreaceae & Calopogonium mucunoides & Gadung \\
5. & Fabaceae & Centrosema pubescens & Kacang asu \\
& & Cyclea barbata & Kembang telang \\
6. & Menispermaceae & Cincau \\
& & Pericampylus glaucus & Akar telur \\
7. & Palmae & Calamus caesius & Bratawali \\
& & Calamus manan & Rotan sega \\
& & Daemonorops sabut & Rotan manau \\
& & Korthalsia rigida & Rotan jungan \\
8. & Piperaceae & Piper betle & Rotan marau \\
& & Piper nigrum & Sirih \\
9. & Schizaeaceae & Piper ornatum & Lada \\
\hline
\end{tabular}

Pada Tabel 1, tampak bahwa famili yang paling banyak ditemukan adalah Convolvulaceae dengan 4 spesies yaitu Ipomoea triloba, Ipomoea cairica, Merremia peltata, Merremia vitifolia dan juga famili Palmae dengan 4 spesies yaitu Calamus caesius, Calamus manan, Daemonorops sabut, Korthalsia rigida. Jenis-jenis yang termasuk dalam famili Convolvulaceae banyak ditemukan di Hutan tropis, seperti juga ditemukan pada Hutan Pendidikan dan Pelatihan Universitas Muhammadiyah Bengkulu merupakan salah satu hutan tropis. Tumbuhan dari famili Convolvulaceae kebanyakan tumbuh di daerah tropis (Suratman et al., 2000). Pada famili Palmae yaitu spesies rotan tumbuh di daerah yang lembab, seperti halnya kondisi di Hutan Pendidikan dan Pelatihan Universitas Muhammadiyah Bengkulu. Famili Palmae dari spesies rotan memiliki pertumbuhan terbaik pada daerah lereng bukit 
yang cukup lembab(Jenis et al., 2017; Marshall et al., 2017; Rodríguez-Quintero \& Gianoli, 2016; Siregar, 2005; Verbeeck \& Kearsley, 2015).

Pada Tabel 1 juga tampak bahwa jenis yang paling sedikit ditemukan adalah Famili Asteraceae, Araceae, Dioscoreaceae, dan Schizaeaceae ditemukan masing - masing 1 spesies. Famili Asteraceae ditemukan 1 spesies karena famili ini menyukai kondisi yang langsung terkena cahaya matahari sedangkan di Hutan Pendidikan dan Pelatihan UMB memiliki intensitas cahaya matahari yang rendah dikarenakan tertutup oleh tajuk pepohonan jenis lainnya. Hal ini didukung oleh Ardyaningsih (2015) menyatakan bahwa anggota famili Asteraceae tumbuh di kawasan yang terpapar cahaya matahari. Famili Araceae yang termasuk kegolongan tumbuhan bawah sangat kurang mendapatkan cahaya karena terhalang tajuk pohon yang terdapat di Hutan Pendidikan dan Pelatihan Universitas Muhammadiyah Bengkulu. Komunitas hutan hujan tropis, memiliki penetrasi cahaya matahari yang sampai pada lantai hutan umumnya rendah sekali (Khoirul, 2014). Pada famili Dioscoraceae hanya 1 spesies ditemukan di Hutan Pendidikan dan Pelatihan Universitas Muhammadiyah Bengkulu yaitu dari spesies Dioscorea hispida. Hal ini diduga disebabkan karena penyebaran atau perkembang-biakan dari spesies ini menggunakan umbi, sehingga penyebarannya hanya terbatas dalam hal ruang maupun jumlah, sedangkan di Hutan Pendidikan dan Pelatihan Universitas Muhammadiyah Bengkulu tidak ada bantuan untuk penyebarannya baik manusia maupun hewan, karena umbi dari spesies ini sangat beracun. Gadung dapat memperbanyak diri hanya dengan bagian umbinya yang diketahui mengandung racun(Mindawati et al., 2013). Famili Schizaeaceae ini sedikit ditemukan di Hutan Pendidikan dan Pelatihan Universitas Muhammadiyah Bengkulu karena dilokasi penelitian ini tajuk pepohonan menutupi cukup rapat sehingga menyebabkan tingkat naungan yang tinggi yang berakibat pada rendahnya intensitas cahaya matahari yang dapat lolos hingga bagian bawah kanopi. Hal ini didukung oleh Ardyaningsih (2015) yang menyatakan bahwa tumbuhan paku dari famili ini menyukai tempat yang terbuka.

Pada Tabel 2 tampak bahwa penyebaran tertinggi ditemukan pada spesies Mikania micrantha, karena penyebaran dari spesies ini menggunakan biji, Mikania micrantha ini memiliki bunga tipe majemuk sehinggadi dalam bunga tersebut terdapat biji yang jumlahnya sangat banyak. Biji-biji tersebut akan disebarkan oleh angin sehingga mudah mendominasi suatu habitat. Biji dari bunga Mikania micrantha ini disebarkan oleh angin sehingga mudah tersebar dan mendominasi suatu habitat. Lain halnya dengan jenis yang penyebaran terendah ditemukan pada spesies Cyclea barbata, Daemonorops sabut, Piper betle. Karena spesies Cyclea barbata ini biasanya hidup pada dataran tinggi yang ketinggiannya lebih dari $720 \mathrm{~m}$ dpl sementara itu ketinggian tempat dari Hutan Pendidikan dan Pelatihan Universitas Muhammadiyah Bengkulu lebih rendah. Hal ini sesuai dengan pendapat yang diutarakan Shodiq (2012) yaitu bahwa spesies Cyclea barbata ini hidup di daerah dengan ketinggian di atas $1.100 \mathrm{~m}$ dpl. Spesies Daemonorops sabut biasanya hidup di daerah dataran rendah. Daemonorps sabut biasanya hidup di dataran rendah sampai ketinggian $400 \mathrm{~m} \mathrm{dpl(Jasni} \mathrm{et}$ al., 2010). Tingkat nilai penyebaran yang terendah ditunjukkan oleh Piper betle dikarenakan tumbuhan ini menyukai tempat yang terbuka, sedangkan di Hutan Pendidikan dan Pelatihan Universitas Muhammadiyah Bengkulu memiliki intensitas cahaya matahari yang rendah atau dengan kata lain terdapat penaungan yang cukup tinggi dari pada kanopi pepohonan lainnya. Muhlisah (2008) mengatakan bahwa tanaman sirih menyukai tempat yang terbuka atau sedikit terlindung. 
Tabel 2. Frekuensi Tumbuhan Liana di Hutan Pendidikan dan Pelatihan Universitas Muhammadiyah Bengkulu

\begin{tabular}{llc}
\hline & No & Numlah Individu \\
\hline 1 & Calamus caesius & 8 \\
2 & Calamus manan & 6 \\
3 & Calopogonium mucunoides & 6 \\
4 & Centrosema pubescens & 8 \\
5 & Cyclea barbata & 4 \\
6 & Daemonorops sabut & 4 \\
7 & Dioscorea hispida & 8 \\
8 & Ipomoea cairica & 8 \\
9 & Ipomoea triloba & 6 \\
10 & Korthalsia rigida & 5 \\
11 & Lygodium flexuosum & 9 \\
12 & Merremia peltata & 5 \\
13 & Merremia vitifolia & 5 \\
14 & Mikania micrantha & 19 \\
15 & Pericampylus glaucus & 7 \\
16 & Piper betle & 4 \\
17 & Piper nigrum & 6 \\
18 & Piper ornatum & 5 \\
19 & Pothos scandens & 15 \\
20 & Tinospora crispa & 5 \\
\hline & Jumlah & 143 \\
\hline
\end{tabular}

Pada Tabel 3 yang memaparkan hasil perhitungan indeks keanekaragaman ( $\left.\mathrm{H}^{\prime}\right)$ Shannon-winner yang diperoleh dalam penelitian ini, menunjukkan bahwa indeks keanekaragaman tumbuhan Liana di Hutan Pendidikan dan Pelatihan Universitas Muhammadiyah Bengkulu Kabupaten Bengkulu Tengah yaitu sebesar H' $=1,226$ di kategorikan indeks keanekaragaman sedang. Karena apabila nilai $\mathrm{H}(1,0-1,5)$ dikategorikan indeks keanekaragaman sedang. Hal ini didukung oleh Arisandy (2011) menyatakan bahwa jika $H^{\prime}>3$ adalah tinggi, jika $1 \leq \mathrm{H}^{\prime} \leq 3$ adalah sedang, dan jika $\mathrm{H}^{\prime}<1$ adalah rendah. Hasil ini menunjukkan bahwa tingkat keanekaragaman jenis Liana di Hutan Pendidikan dan Pelatihan Universitas Muhammadiyah Bengkulu Kabupaten Bengkulu Tengah termasuk golongan sedang. Karena pengaruh dari faktor kelembaban yang tinggi akibat dari tajuk pepohonan yang rapat(Mohandass et al., 2017; Nasution et al., 2015; Sirami et al., 2016). Tumbuhan yang tergolong Liana mampu tumbuh dengan baik pada tegakan yang tajuknya tidak terlalu rapat dan tidak terlalu terbuka. Penutupan tajuk pohon yang lebih besar nampaknya akan menghambat pertumbuhan Liana (Asrianny et al., 2008).

Faktor-faktor lingkungan pada lokasi penelitian berperan penting dalam mempengaruhi pertumbuhan dan perkembangan tumbuhan tumbuhan tergolong Liana. Ketinggian lokasi penelitian adalah $\pm 720 \mathrm{~m}$ dengan suhu yang berkisar antara $27^{\circ} \mathrm{C}-31^{\circ} \mathrm{C}$ sedangkan kelembapan berkisar antara $76^{\%}-87 \%$. Dpl tentunya akan mempengaruhi tingkat keragaman tumbuhan Liana. Dapat dilihat dari hasil pengukuran bahwa di Hutan Pendidikan dan Pelatihan Universitas Muhammadiyah Bengkulu Kabupaten Bengkulu Tengah memiliki udara yang tergolong tinggi sehingga tumbuhan Liana dapat berkembang dengan baik di hutan ini. Tumbuhan Liana tumbuh di hutan hujan tropik pada kisaran suhu rata-rata $25^{\circ} \mathrm{C}$ 
dan kelembaban berkisar dari 60-100\% (Patrick Addo-Fordjour et al., 2016; Schnitzer, 2015).

Tabel 3. Indeks Keanekaragaman Jenis (H') Tumbuhan Liana di Hutan Pendidikan dan Pelatihan Universitas Muhammadiyah Bengkulu

\begin{tabular}{llllll}
\hline Nama Spesies & $\begin{array}{l}\text { Jumlah } \\
(\mathrm{Ni})\end{array}$ & $\mathrm{Pi}$ & Log Pi & Pi Log Pi & H' \\
\hline Calamus caesius & 8 & 0.055 & -1.259 & -0.069 & 0.069 \\
Calamus manan & 6 & 0.041 & -1.387 & -0.056 & 0.056 \\
Calopogonium mucunoides & 6 & 0.041 & -1.387 & -0.056 & 0.056 \\
Centrosema pubescens & 8 & 0.055 & -1.259 & -0.069 & 0.069 \\
Cyclea barbata & 4 & 0.027 & -1.568 & -0.042 & 0.042 \\
Daemonorops sabut & 4 & 0.027 & -1.568 & -0.042 & 0.042 \\
Dioscorea hispida & 8 & 0.055 & -1.259 & -0.069 & 0.069 \\
Ipomoea cairica & 8 & 0.055 & -1.259 & -0.069 & 0.069 \\
Ipomoea triloba & 6 & 0.041 & -1.387 & -0.056 & 0.056 \\
Korthalsia rigida & 5 & 0.034 & -1.468 & -0.049 & 0.049 \\
Lygodium flexuosum & 9 & 0.062 & -1.207 & -0.074 & 0.074 \\
Merremia peltata & 5 & 0.034 & -1.468 & -0.049 & 0.049 \\
Merremia vitifolia & 5 & 0.034 & -1.468 & -0.049 & 0.049 \\
Mikania micrantha & 19 & 0.132 & -0.879 & -0.116 & 0.116 \\
Pericampylus glaucus & 7 & 0.048 & -1.318 & -0.063 & 0.063 \\
Piper betle & 4 & 0.027 & -1.568 & -0.042 & 0.042 \\
Piper nigrum & 6 & 0.041 & -1.387 & -0.056 & 0.056 \\
Piper ornatum & 5 & 0.034 & -1.468 & -0.049 & 0.049 \\
Pothos scandens & 15 & 0.104 & -0.982 & -0.102 & 0.102 \\
Tinospora crispa & 5 & 0.034 & -1.468 & -0.049 & 0.049 \\
\hline Total & 143 & 0.981 & -27.014 & -1.226 & 1.226 \\
\hline
\end{tabular}

\section{KESIMPULAN}

Keanekaragaman tumbuhan Liana yang terdapat di kawasan Hutan Pendidikan dan Pelaihan Universitas Muhammadiyah Bengkulu cukup tinggi, yaitu ditemukan 143 individu dari 20 spesies yang termasuk kedalam 9 famili. Indeks keanekaragaman untuk tumbuhan Liana di dapat nilai 1.226 (kategori sedang). Penyebaran paling banyak dan mendominasi habitat adalah dari spesies Mikania micrantha dengan jumlah 19 individu, dikarenakan sistim penyebaran dari spesies ini menggunakan biji. Faktor yang mempengaruhi adalah dikarenakan kawasan hutan memiliki tajuk pohon yang sangat rapat sedangkan tumbuhan Liana akan dapat tumbuh dengan baik pada hutan yang tajuknya cukup rapat dan cukup terbuka.

\section{DAFTAR PUSTAKA}

Addo-Fordjour, P., Rahmad, Z. B., \& Burnham, R. J. 2016. Intercontinental comparison of liana community assemblages in tropical forests of Ghana and Malaysia. Journal of Plant Ecology, (December 2017), rtw082. https://doi.org/10.1093/jpe/rtw082

Addo-Fordjour, P., Rahmad, Z. B., \& Shahrul, A. M. S. 2016. Liana species composition, dominance and host interactions in primary and secondary forests in Malaysia. Tropical Ecology, 57(3), 513-522.

Ardyaningsih, D. 2015. Keanekaragaman Famili Asteraceae di Kawasan Kampus IPB 
Darmaga Bogor. Institut Pertanian Bogor.

Arisandi, D.2011. Keragaman dan Kerapatan Tumbuhan Liana yang terdapat di daerah Aliran Sungai Randi yang mengalri Desa Tanjung Agung Kecamatan Karang Jaya Kabupaten Musi Rawas. Universitas Muhammadiyah Bengkulu.

Asrianny, Marian, \& Oka, N. 2008. Keanekaragaman dan Kelimpahan Jenis Liana pada Hutan ALam di Hutan Pendidikan Universitas Hasanuddin. Jurnal Perennial, 5(1), 2330.

Hilje, B., Stack, S., \& Sánchez-Azofeifa, A. 2017. Lianas abundance is positively related with the avian acoustic community in tropical dry forests. Forests, 8(9). https://doi.org/10.3390/f8090311

Indriyanto. 2010. Ekologi Hutan. Jakarta: Bumi Aksara.

Jasni, Damayanti, R., Kalima, T., Malik, J., \& Abdurachman. (2010). Atlas Rotan Indonesia (Jilid II). Bogor: usat penelitian dan Pengembangan Keteknikan Kehutanan dan Pengolahan Hasil Hutan.

Jenis, K., Sekunder, H., Jenis, K., Struktur, D. A. N., \& Sekunder, H. 2017. Komposisi Jenis Dan Struktur Hutan Sekunder Di Nunuka Bolaang Mongondow Utara, 27-36.

Khoirul.2014. Identivikasi Tumbuhan Famili Araceae di Cagar Alam Tangale Kabupaten Gorontalo. Universitas Negeri Gorontalo.

Marshall, A. R., Coates, M. A., Archer, J., Kivambe, E., Mnendendo, H., Mtoka, S., Njilima, F. M. 2017. Liana cutting for restoring tropical forests: a rare palaeotropical trial. African Journal of Ecology, 55(3), 282-297. https://doi.org/10.1111/aje.12349

Mindawati, N., Nurohmah, H., \& Akhmad, C. 2014. Kayu Raja Andalan Sumatera. Bogor: Forda Press.

Mohandass, D., Campbell, M. J., Hughes, A. C., Mammides, C., \& Davidar, P. 2017. The effect of altitude, patch size and disturbance on species richness and density of lianas in montane forest patches. Acta Oecologica, 83(March), 1-14. https://doi.org/10.1016/j.actao.2017.06.004

Muhlisah, F. 2008. Tanaman Obat Keluarga. Jakarta: Penebar Swadaya.

Nasution, T., Aditya, E., Iskandar, P., \& Ismaini, L. 2015. Keragaman flora berpotensi dan komposisi vegetasi di Gunung Marapi, Sumatera Barat Diversity of potential flora and vegetation composition in Mount Marapi, West Sumatra. Pros Sem Nas Masy Biodiv Indon, 1(6), 2407-8050. https://doi.org/10.13057/psnmbi/m010613

Rodríguez-Quintero, W. D., \& Gianoli, E. 2016. Abundance and diversity of lianas in a Neotropical dry forest: the influence of soil moisture. Plant Ecology and Evolution, 149(3), 329-334. https://doi.org/10.5091/plecevo.2016.1233

Rosmeri, V., \& Monica, B. 2013. Pemanfaatan Tepung Umbi Gadung (Dioscorea hispida) dan Tepung Mocaf (Modified casava flour) Sebagai Bahan Substitusi dalam Pembuatan Mie basah, Mie kering, Mie instan. Jurnal Teknologi Kimia Dan Industri, 2(2), 246-259.

Schnitzer, S. A. 2015. Biogeographic patterns in liana abundance and diversity in tropical forests, (April 2016).

Shodiq, A. 2012. Uji Aktivitas Antioksidan Ekstrak dan Fraksi Daun Cincau Hijau Rambat (Cyclea Barbata) dan Identifikasi Golongan Senyawa DariFraksi yang Paling Aktif. Univesitas Indonesia.

Sirami, E. V., Marsono, D., Sadono, R., \& Imron, M. A. 2016. Struktur, Keragaman Dan 
Asosiasi Komunitas Tumbuhan Pemanjat Dengan Populasi Alam Merbau Di Taman Wisata Alam Gunung Meja Manokwari-Papua Barat. J. Manusia Dan Lingkungan, 23 (1)(1), 82-91.

Siregar, E. 2005. Potensi Palem Indonesia. USU Repository, 3(2), 1-11.

Suratman, Priyanto, D., \& Setyawan, A. 2000. Analisis Keragaman Genus Ipomoea Berdasarkan Karakter Morfologi. Biodiversitas, 1(2), 72-79.

Verbeeck, H., \& Kearsley, E. 2015. The importance of including lianas in global vegetation models. Proceedings of the National Academy of Sciences, 113(1), 201521343. https://doi.org/10.1073/pnas.1521343113 